\title{
164. On the Two Discontinuities in the History of the Order Conchostraca
}

\author{
By Teiichi Kobayashi, M. J. A.
}

(Comm. Dec. 12, 1972)

The Conchostracan fossils are widely distributed in non-marine sediments from Devonian or Upper Silurian to Upper Cretaceous, but none is known from the Tertiary so that no link exists between fossil and living Conchostracans. Their possible ancestors are known from Cambrian marine sediments, but a discontinuity of fossil record exists also between marine and non-marine Conchostracans at the Ordovician and Silurian periods.

These ancestors are Lepiditta, Fordilla and probably Lepidella and Modioloides which are provisionally involved in the Lepidittidae. Lepiditta with a subcentral umbo on a straight dorsal margin is allied to the Asmussiidae, while Fordilla resembles the Lioestheriidae in carapace outline and other aspects. They, however, reveal no Estherian type of minute sculpture in the interspaces of growth lines. It has been a long current opinion prevalent in palaeontology that they are neither Mollusca nor Ostracoda, but Estherian allies or ancestors. A new suborder, Praestheritina, is proposed for them.

The fossil non-marine Conchostraca can be classified into two major groups with and without radial carinae, costae or ribs. The former which is named here Leaiina is an extinct suborder. On the contrary, the latter which is denominated Estheritina, includes many forms quite similar to the living Spinicaudata beside many other well specialized ones totallly extinct.

Soft animals including eggs of the Estheritina are known only of the following four species.

1. Limnestheria ardra Wright, 1920, from the Carboniferous of Ireland.

2. Estheria cebenensis Grand 'Eury by Dechaseaux, 1951, from the Carboniferous of Gard, France.

3. Estheria minuta by Bill (1914) from the Lower Triassic of Elsace.

4. Lynceus (Limnetis) stchukini Chernyshev, 1940, from the Lower Cretaceous of Transbaikalia, Siberia.

They contain part of a fornix, antenules, antennae, mandibles, claspers, other appendages, trunks, telsons and (?) caudal furca which would be sufficient to convince oneself of their being Conchos- 
tracans, but they are too fragmentary to locate Limnestheria ardra either in the Laevicaudata or in the Spinicaudata. Therefore its reference is widely divergent to the Lynceidae, Limnadiidae or Cyzicidae among neontologists and palaeontologists.

With an aid of Huzita I (1943) have examined over 100 species and varieties in 7 genera of the Cyzicidae and Leptestheriidae in Deday's monograph and a few other papers to find any generic characteristic of carapace outline, growth lines and sculpture, but it was in vain.

Because the lack of growth lines is the characteristic of the Lynceidae, Lynceus stchukini has been generally accepted as a solitary fossil species of the family and accordingly the Laevicaudata. Its carapace outline is, however, so elongated that it looks more allied to the Cyzicidae and Leptestheriidae than Lynceus. From these characteristics this species may be said intermediate in carapace biocharacters between the two suborders.

Thus, any non-rayed Conchostracan is impossible to be located at an exact taxonomic position by carapace morphology. It is also impossible to classify it into a suborder even by soft part anatomy, seeing that these four species bearing soft part's remains cannot be placed either in the Laevicaudata or in the Spinicaudata definitely. I must emphasize here that these taxonomic discrepancies are, biogeologically speaking, at the two discontinuities in fossil record in the Tertiary seventy million years and about 100 myr. of the Ordovician-Silurian periods. Under such a circumstance I was compelled to classify fossil estherians and allied fossils by the carapace morphology. My classification of the non-marine fossil Conchostraca in 1954 is reconsidered and revised as below on the basis of recent advancements made by Novojilov (1960), Defretin (1965), Tasch (1969) and others.

Suborder Estheritina: non-rayed Conchostraca.

Superfamily Lioestherioidea including Lioestheriidae, Rhabdostichidae, Asmussiidae and Estheriinidae.

Superfamily Palaeolimnadiopseoidea including Palaeolimnadiopseidae and Ipsiloniidae.

Superfamily Vertexioidea including Vertexiidae and Pemphilimnadiopsidae.

Suborder Leaiina: rayed Conchostraca.

Superfamily Estherielloidea including Estheriellidae and Monoleiolophidae.

Superfamily Leaioidea including Leaiidae, Amphikoilidae, Rostroleaiidae and (?) Echinolimnadiidae.

As mentioned above, the derivation of the Lioestherioidae from the Lepidittidae is suggested by their morphological resemblances. 


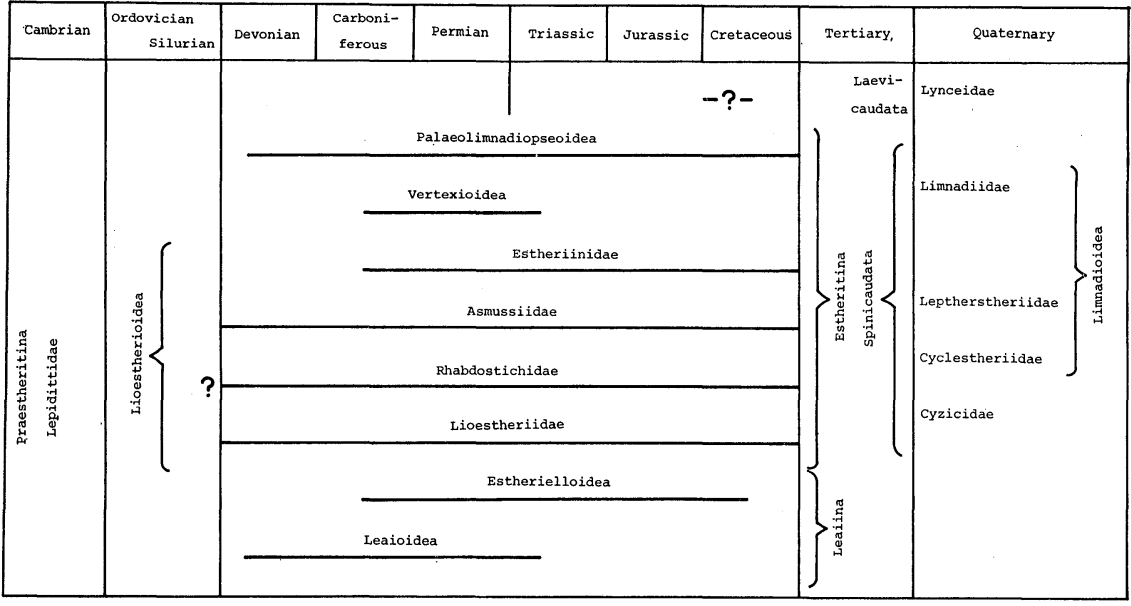

Rhabdostichus s. l., Archaeositum butchoi (Péneau) for example, is an oldest member of the superfamily which was probably still capable of surviving in the late Silurian-Devonian sea. The distribution of the Conchostraca to the limnic facies from the paralic Devonian in Europe suggests their invasion into fresh water environments. (See Fig. 23, Kobayashi, 1954.)

The Conchostracan evolution at the time of the Caledonian orogeny was quite explosive. Three families of the Lioestherioidea in addition to the Leaioidea and Palaeolimnadiopseoidea have appeared through the Middle Devonian period. In the Carboniferous period when Hercynian orogeny was intense another important step of development was advanced as indicated by the addition of the Estheriinidae, Vertexioidea and Estherielloidea.

The Palaeolimnadiopseoidea and Vertexioidea were evolved from the Liaoestherioidea respectively toward the limnadiform and corniform trends. The former trend is in the lateral protrusion of the dorsal margin and the sinuation of the lateral margin. The latter is in the projection of spines or tubercles in the umbonal area as seen in Cornia and Vertexia. The Leaioidea and the Estherielloidea were issued from the Lioestherioidea stock respectively by addiiton of regularly spaced radial carinae of a small definite number and by producing radial costae or ribs, mostly numerous, but rarely one or a few, which are commonly irregular in number and length, but mostly obsolete near the umbo.

These four superfamilies branched off from the Lioestherioidea toward these four trends of specialization in the ages of the Caledonian and Hercynian orogenies. The expanse of time from late Carboniferous to early Triassic when all of the five superfamilies 
flourished was the acme of the Conchostraca.

In 1954 I have pointed out that the center of the Conchostracan distribution in the northern continents was shifted from the Atlantic to the Pacific side during the Permo-Triassic period in accordance with the shifting from the Hercynian-Appalachian orogeny in the west to the Akiyoshi orogeny in the east side. Since then the Permian and Mesozoic Conchostracans were so well clarified and amplified in Asia by Chang, Chen, Defretin, Kapel'ka, Krasinets, Kusumi, Molin, Novojilov, Ozaki, Varentsov and others that the shifting of the center is now thoroughly warranted.

During the Triassic period when the Akiyoshi cycle of orogeny reached the climax, the Vertexioidea and Leaioidea died out. Later the Estherielloidea disappeared in the Middle Cretaceous times when the Sakawa orogenic cycle was paroxysmal. At length the Lioestherioidea and the Palaeolimnadiopseoidea also terminated by the end of the Cretaceous period. Thus the history of the limnobios were intimately related to the orogenic cycle by which the environment of their habitats were greatly changed.

It is a remarkable fact that the specialized branches were shortranged, while the non-specialized Lioestherioidea represent the persistent trunk. Part of the Estheritina must have survived through the Tertiary period, because it is undeniable that its descendants are the living Conchostraca.

The appearance of the Laevicaudata and Spinicaudata in the Quarternary period was quite sporadical. They reveal a phyletic rejuvenescence through the glacial and interglacial ages when climate and hydrogeography were repeatedly changed. The explosive divergence of the Conchostraca at the transition between the Silurian and Devonian periods might have been related also to similar environmental changes caused by the Caledonian mountain-building.

In view of the facts on the maximum thriving of living Conchostracans in the Donau and other inland basins in the temperate zone warm in hot season (Kobayashi and Park, 1943) and the extensive dispersal of durable egg-capsules by wind, the topographic change, palaeo-wind and palaeo-temperature must have been particularly important geological factors to describe the rise and fall in the history of the Conchostraca in cooperation with the orthogenetic specialization, phylogenetic senility and other biological factors.

The revised classification of the fossil Conchostraca will be described in detail in a paper now in preparation. 


\section{References}

Chernyshev, B. I. (1940) : Mesozoic Branchiopoda from Turkestan and Transbaikalia. Acad. Nauk Ukrin SSR. Inst. Geol. Sci. Jour. Geol., 7, Issue 3, pp. 543, pl. 1-3.

Defretin-Lefranc, S. (1965) : Etude et révision du Phyllopodes, Conchostracés en province d'U. R. R. S. Ann. Soc. géol. Nord, 85, pp. 15-48, pl.1-3.

Dechaseaux, C. (1951): Contribution à la connaissance des esthéries fossiles. Paléontologie, 37, pp. 125-132, pl. 1.

Kobayashi, T. (1954): Fossil Estherians and allied fossils. Jour. Fac. Sci. Univ. Tokyo, sec. 2, 9, part 1, pp. 1-192.

Kobayashi, T., and Huzita, A. (1943): Estherites and its relation to the genera of living Estherids. Proc. Imp. Acad. Tokyo, 19, no. 3, pp. 161-167.

Kobayashi, T., and Park, No Shih (Y. Kido, 1943) : Climatic effect on the distribution of living Estherids and its relation to the morphic characters of their carapaces. Jour. Geol. Soc. Japan, 50, pp. 311-317.

Novojilov, N. (1960) : Conchostraca. In Orlov's Osnoby Paleontologii, 8, pp. 216253.

Tasch, F. (1969) : Branchiopoda. In Moore's Treatise of Invertebrate Paleontology, Part R. Arthropoda, 4, pp. 128-191. 